\title{
AN ARIZONA BARK SCORPION (CENTRUROIDES SCULPTURATUS) FOUND CONSUMING A VENOMOUS PREY ITEM NEARLY TWICE ITS LENGTH
}

\author{
Michael M. Webber ${ }^{1,2}$ and Matthew R. Graham 1,3
}

\begin{abstract}
Arizona bark scorpions (Centruroides sculpturatus Ewing) are commonly found throughout the Sonoran Desert in southwestern North America, and they are well known for being the most venomous scorpion in the United States. Despite their medical significance, C. sculpturatus remains ecologically understudied, and little is known regarding its natural foraging and feeding behaviors. Here, we present the first documented case of C. sculpturatus feeding on the Sonoran Desert centipede (Scolopendra polymorpha Wood) in the wild.
\end{abstract}

Resumen.-Los Alacranes de Corteza de Arizona (Centruroides sculpturatus Ewing), por lo general, se encuentran en todo el Desierto de Sonora, en el sudoeste de Norteamérica, y se conocen por ser los alacranes más venenosos de los Estados Unidos. A pesar de su importancia medicinal, C. sculpturatus no ha sido my estudiado desde el punto de vista ecológico, y se conoce muy poco sobre su comportamiento natural de forrajeo y alimentación. A continuación presentamos el primer caso documentado de un C. sculpturatus alimentándose de un ciempiés (Scolopendra polymorpha Wood) en medio del desierto.

The Arizona bark scorpion, Centruroides sculpturatus Ewing, is a well-documented species found throughout the Sonoran Desert in southwestern North America (Polis 1990). All bark scorpions belong to the medically significant family Buthidae (Keegan 1980), and C. sculpturatus in particular is notorious for being the most venomous species in the United States and for being highly dangerous to humans (Patterson 1960, Berg and Tarantino 1991, LoVecchio and McBride 2003). Centruroides sculpturatus is a common pest species, often entering homes and thriving in xeric southwestern landscaping, so encounters and human envenomations are quite common. In nature, $C$. sculpturatus inhabits rocky terrain, canyons, and riparian habitats, where it hides during the day under rocks and fallen vegetation, and in rock crevices (Crawford and Krehoff 1975, Likes et al. 1984, Polis 1990). Centruroides sculpturatus is known to feed on several species of invertebrates (e.g., spiders, scorpions, and sulfugids) and has been observed exhibiting both active and ambush foraging behaviors (McCormick and Polis 1990). Although its venom is relatively well characterized (e.g., Curry et al. 1983, Rowe and Rowe 2008), the species remains ecologically understudied. In this contribution, we provide notes on our observation of a C. sculpturatus consuming a Sonoran Desert centipede, Scolopendra polymorpha Wood, in the wild. As far as we are aware, this is the first report of a predator-prey interaction between these 2 species.

During a survey for C. sculpturatus in rocky habitats just west of Quartzsite, Arizona $\left(33.634495^{\circ},-114.304125^{\circ}\right)$, on 25 June 2012 , we discovered a mature female C. sculpturatus consuming a $S$. polymorpha. The encounter occurred at night (ultraviolet light was used to detect scorpions; Stahnke 1972), and the surrounding habitat consisted of boulder-strewn hills and typical Sonoran Desert vegetation, such as saguaro (Carnegiea gigantea Britton and Rose), creosote (Larrea tridentata Coville), cholla (Cylindropuntia spp.), and ocotillo (Fouquieria splendens Engelmann). The scorpion was clinging to the vertical surface of a rock, with its anterior end pointed downward and the centipede dangling from its chelicerae and chelae (Fig. 1). At the start of our observation, the scorpion had already consumed most of the cephalic region of the centipede. The scorpion was approximately $28 \mathrm{~mm}$ in body length (from the anterior margin of the carapace to the posterior margin of tergite VII). The condition of the centipede was too poor

\footnotetext{
${ }^{1}$ School of Life Sciences, University of Nevada Las Vegas, 4505 Maryland Parkway, Las Vegas, NV 89154

${ }^{2}$ E-mail: webberm4@unlv.nevada.edu

${ }^{3}$ Biology Department, Eastern Connecticut State University, 83 Windham Street, Willimantic, CT 06226
} 


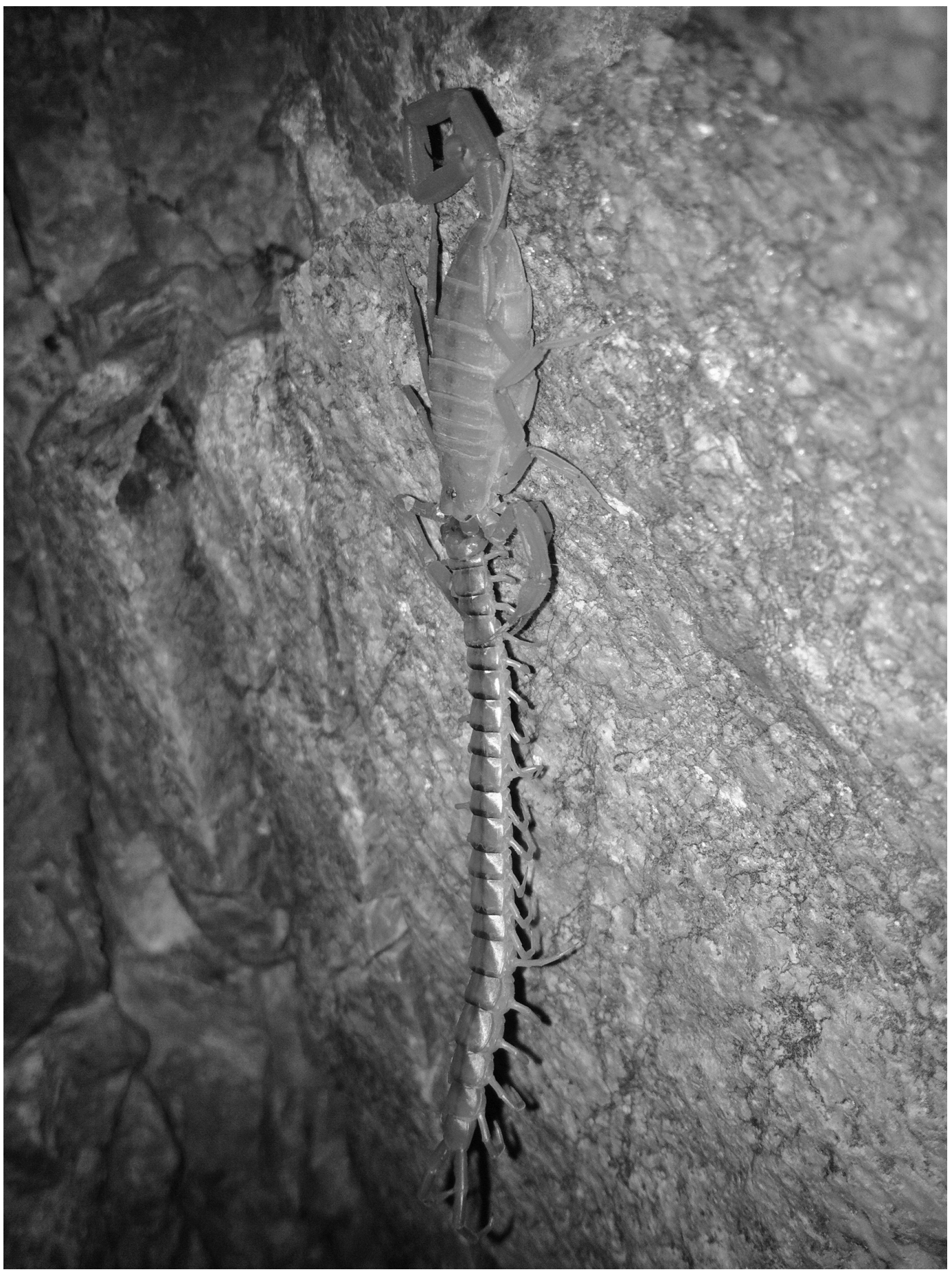

Fig. 1. An Arizona bark scorpion, Centruroides sculpturatus Ewing, observed feeding on a Sonoran Desert centipede, Scolopendra polymorpha Wood, near Quartzsite, Arizona. 
to allow a precise measurement of total body length, but based on the remaining portion, the specimen appeared to be approximately $56 \mathrm{~mm}$ in length, twice the length of the scorpion.

Centruroides sculpturatus is a relatively small-bodied scorpion that possesses slender chelae, so we find it astonishing that this species would be capable of catching and subduing a prey item of this size. Centruroides sculpturatus possesses an especially potent venom (LoVecchio and McBride 2003), perhaps allowing these scorpions to quickly subdue large and dangerous prey items. Furthermore, the scorpion was actively consuming the centipede while the scorpion was positioned upside down, which appears to be a common behavior of Centruroides spp. (MMW and MRG, personal observation; also see figures in McReynolds 2012). Conceivably, this method may allow bark scorpions to more easily secure prey by keeping the body and legs of large prey items like centipedes off of the ground, thus reducing the likelihood of prey escape or bodily injury to the scorpion by defensive behaviors of prey. Additional research investigating the prey-handling behaviors of C. sculpturatus against dangerous and nondangerous prey items could uncover strategies used by this species to subdue potentially dangerous prey items like large centipedes.

Although our account documents the first record of C. sculpturatus preying upon S. polymorpha, centipedes are known to be predators of scorpions (McCormick and Polis 1990). Relative body size may be an important factor determining the outcome of antagonistic encounters between these 2 species. Thus, we hypothesize that predation on centipedes is not always successful, especially in potential confrontations between large S. polymorpha and small C. sculpturatus. In desert ecosystems where encounters with prey may be rare, the water and nutrients available from large, thick-bodied arthropods like centipedes could be worth the risk.

We thank Dr. Tereza Jezkova and anonymous reviewers for providing comments that improved the final version of this manuscript.

\section{Literature Cited}

Berg, R.A., ANd M.D. Tarantino. 1991. Envenomation by the scorpion Centruroides exilicauda (C. sculpturatus): severe and unusual manifestations. Pediatrics 87:930-933.

Crawford, C.S., and R.C. Krehoff. 1975. Diel activity in sympatric populations of the scorpions Centruroides sculpturatus (Buthidae) and Diplocentrus spitzeri (Diplocentridae). Journal of Arachnology 2: 195-204.

Curry, S.C., M.V. Vance, P.J. Ryan, D.B. Kunkel, and W.T. NoRThEY. 1983. Envenomation by the scorpion Centruroides sculpturatus. Journal of ToxicologyClinical Toxicology 21:417-449.

KeEgan, H.L. 1980. Scorpions of medical importance. University Press of Mississippi, Jackson, MS.

Likes, K., W. Banner JR., and M. Chavez. 1984. Centruroides exilicauda envenomation in Arizona. Western Journal of Medicine 141:634.

LoVecchio, F., And C. McBride. 2003. Scorpion envenomations in young children in central Arizona. Journal of Toxicology-Clinical Toxicology 41:937-940.

MCCormick, S.J., AND G.A. Polis. 1990. Prey, predators and parasites. Pages 294-320 in G.A. Polis, editor, The biology of scorpions. Stanford University Press, Stanford, CA.

MCReynolds, C.N. 2012. Ontogenetic shifts in microhabitat use, foraging and temporal activity for the striped bark scorpion Centruroides vittatus (Scorpiones: Buthidae). Euscorpius 144:1-19.

Patterson, R.A. 1960. Physiological action of scorpion venom. American Journal of Tropical Medicine and Hygiene 9:410-414.

PoLIS, G.A. 1990. The biology of scorpions. Stanford University Press, Stanford, CA.

Rowe, A.H., AND M.P. Rowe. 2008. Physiological resistance of grasshopper mice (Onychomys spp.) to Arizona bark scorpion (Centruroides exilicauda) venom. Toxicon 52:597-605.

Stahnke, H.L. 1972. U.V. light, a useful field tool. BioScience 22:604-606.

Received 27 December 2012

Accepted 10 June 2013 